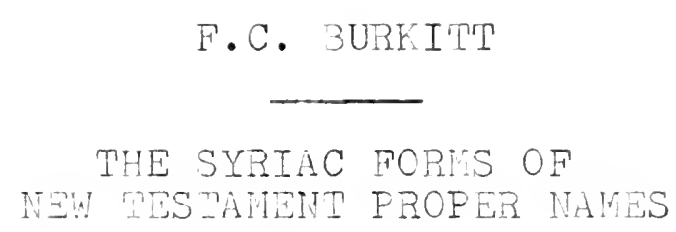

BS2545

.N2B9 


$$
\text { BS2545 }
$$

N2B9 


\title{
THE BRITISH ACADEMY
}

\section{The Syriac Forms of}

\section{New Testament Proper Names}

\author{
By \\ F. C. Burkitt
}

Fellow of the Academy

[From the Proceedings of the British Academy, Vol.V]

\section{London}

Published for the British Academy

By Henry Frowde, Oxford University Press

Amen Corner, E.C.

Price Tro Shillings net 
The following works are quoted by an abbreviated title.

Dalman.-G. Dalsan, Grammatik des Jüdisch-Palästinischen Aramäisch (Leipzig, 1894).

Grilliam.-G. H. Gwilliam, Tetra-evangelium sanctum (Oxford, 1901). [The number after Grvilliam signifies a Syriac MS., not the page of his book.]

Itinera Sancta.-Vol. xxxviii of the Vienna Corpus Script. Eccl. Lat., edited by P. Geyer (1898).

Neubaner.-A. Neubauer, La Géographie du Talmud (Paris, 1868).

OS.-P. de Lagarde, Onomastica Sacra (Göttingen, 1887), quoted by the marginal pagination. 


\section{THE SYRIAC FORMS OF NEW TESTAMEN'T PROPER NAMES

\author{
By F. C. BURKI'T'I \\ FELLOW OF THE ACADEMY
}

Read January 24, 1912

'Tri subject I have chosen for this Paper sounds, I fear, rather dry and technical, so that it may not be out of place to begin by claiming that it presents one element of general interest. The Pilgrim from Palestine, with his staff and his scallop-shell and his tales of the Holy Land, is one of the most picturesque figures of the middle ages: it will be my task this afternoon to introduce you to the earliest of that band, the earliest that has left any record. His tale is told in a dead language, and perhaps not all his archacology is correct, but he cleserves to be heard with the respect due to a pioneer.

The New 'Testament is a collection of Greek writings, and it is not till the last quarter of the second century A. D. that there is any evidence of efforts to translate it into other tongues. But in the period between 170 and 200 the Gospels, Acts, and Pauline Epistles were translated into Latin in the West, at Rome or Carthage, and into Syriac in the East, at Edessa in the Euphrates Valley. The translation of the New 'Testament into Latin presented no special diffieulty, and least of all in the proper names. 'There is, of course, a right way and a wrong, as those know who have read Professor Housman's amusing article in the last number of the Journal of Philology on Greek Nouns in Latin P'oetry'. But the points raised are, after all, of subsidiary interest. The Latin translator had merely to give the Latin letter which custom and authority prescribed as equivalent to the Greek letter. He had no need to be wise above that which had been written: it is a pretty question whether we ought to write Pharao

${ }^{1}$ It is worth while reeording the fact that the oldest Christian MSS. support Professor Housman's general conclusions, e. g. $k$ has 'Heroden', and the W'̈̈rzburg Palimpsest in Jeremiah xiii has 'Enf 'aten'. 
or Farao, but all that either form tells us is that the title of the king of Egypt is spelt $\phi_{a p a \omega}$ in Greek.

The translator from Greek into Syriac is in a very different case. Syriac, the former common speech of the Euphrates Valley, is a Semitic language, the first cousin of Hebrew. Like Hebrew, many of the rowels do not appear in writing, and those that are written are given in a notation that, according to our ideas, is singularly imperfect. On the other hand, many distinctions are made, especially in the sibilants, which disappear in the Greek, and (as in Hebrew) there are four true guttural sounds which are not represented in Greek at all.

It is easy enough to transliterate true Greek Proper Names into Syriac. They look indeed rather clumsy, and without the insertion of vowel sigus the transliterations are often ambiguous ${ }^{1}$. The real difficulty and the real interest arises when, as so often in the New 'Testament, the Proper Name in the Greek is itself a transliteration or adaption of a Semitic word. Greek is a poor language for such a purpose, and the Semitic words lose in transliteration many of their most striking characteristics. The Patriarchs

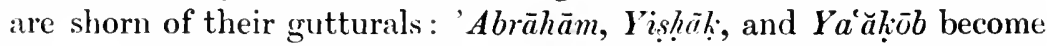

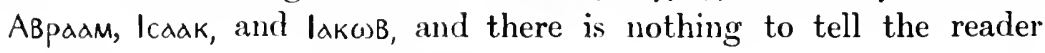
that Abraham's $h$ is an English $h$, Isaac's is a $k h$ (or very nearly), while Jacob's is the peculiar Semitic 'ain. Moreover, without private information, the retranslator from Greek into a Semitic language would not know where to put the gutturals in : as a matter of fact, the $h$ in A comes instead of the first $\alpha$, and the ' in $\operatorname{Ia\kappa \omega \beta }$ comes between the $a$ and the $\kappa$.

These difficulties lie in the nature of the languages and confront a translator as soon as he sets about his task. When therefore we find that the older Syriac Versions, speaking generally, do not simply transliterate the New 'Testament Proper Names, but give the proper Semitic equivalent, we are obviously in the presence of a learned achievement, of a work of Biblical learning which demands elucidation and explanation. How did the Syriac translator come by his information?

A few words may here be said on the Syriac Versions of which account will be taken here. The Syriac Vulgate, commonly called

1 The commemoration of a certain $\Delta n \dot{\lambda} \lambda \eta$ at Nicomedia on March 25 is given by Lietzmann from the ancient Syriac Martyrology as 'dvl's'. It doesn't look quite 80 bad in Syriac letters! 
the Peshitta, comprises the greater part of the Old and New Testaments. It is preserved with a surprising absence of variation in many MSS., some of which are as old as the fifth century. 'Tlie Canonical Books of the Old Testament were translated originally direct from the Hebrew, probably by Jews rather than Christians; but certain books, notably that of Isaiah, seem to have been revised from the Greek Bible. 'The so-called 'A pocrypha', such as the Book of Wisdom, must have been translated from the Greek. 'The text of the Peshitta in the New 'lestament is also a revision; it is now generally recognized that this revision was made by Rabbula, Bishop of Edessa from 411 to 435. No MS. of the Acts or Pauline Epistles previous to this revision survives, but two MSS. of the Gospels are known, Cureton's MS. and the Sinai Palimpsest, which represent the texts current before Rabbula. Besides these MSS. we have the scanty remains of Syriac literature earlier than the fifth century, notably the works of Aphraates (345 A.D.) and Ephraim (d. 373 A.D.). A large mass of evidence tends to shew that the form in which the Gospel generally circulated among Syriac-speaking Christians before the time of Rabbula was not the Four separate Gospels, but 'Tatian's Diatessaron: this work survives in a late Arabic translation, but the Syriac text from which this Arabic translation was made had been assimilated wholesale to the Peshitta. In any case, the Arabic cannot be depended on for details connected with the spelling of Proper Names.

Our three chief authorities, therefore, are the Sinai Palimpsest (S), the Curetonian MS. (C), and the Peshitta (P). A later Syriac version of the parts of the New Testament not comprised in the Peshitta (viz. 2 Peter, 2 and 3 John, Jude, and the Apocalypse), made in the sixth century for Philoxenus of Mabbogh, is cited as $\phi$. Many of the Proper Names in the Gospels are mentioned by Aphraates, whose works include a Homily on the Gospel Genealogies: his evidence, where necessary, is quoted as $A$. It is clear that for the most part Aphraates used the Diatessaron ${ }^{1}$.

Rabbula's revision of the text was in many ways drastic and thorough-going, but fortunately the Proper Names were very little altered. His procedure was not unlike that of the English Revisers of 1881, who also left the Proper Names much as they were, though in other respects they made alterations in the direction of conformity to the Greek. The proof of the above statement lies in the very

1 The number after $\mathrm{A}$ is the page in Patrologia syriaca, vol. i (1394), vol. ii (1907). 
numerous agreements of $s, \mathbf{C}$, and $\mathbf{P}$, and the very few cases of actual difference. For instance, the final $b$ in 'Beelzebub' is attested by no Greek Ms., so far as I know, but Rabbula retains it, following both $\rightarrow$ and $\mathrm{C}$, and also $\mathrm{A}$ \% 14 .

'The agreement between S, C, and I' in the Gospels is the justifiation for using $\mathbf{P}$ in the rest of the New 'lestament, where $\mathbf{S}$ and $\mathbf{C}$ : fail us. It should, of course, be remarked that the definite agreenent of $\mathrm{P}$ with SC is naturally confined to those Proper Names which are transmitted without variant in the Greek. Naturally it may happen that there is a variant in a name, and in such cases $l$ 'and S C' are sometimes found on opposite sides, e. g. in Joh i 28 s C support 'Bethabara', while P supports 'Bethany'. But such cases are comparatively rare, and do not seriously call in question the general faithfulness of 1 ' to the nomenclature of the Old Syriac Version.

A glance at SC and $\mathrm{P}$ shews that the general practice of the translator of the New Testament into Syriac, whoever he may have been, was to give the Old 'Testament equivalent for the Proper Names, as far as this could be done. A discussion of this part of the subject will be found in Evangelion da-Mepharreshê, vol. ii, Pl. 201-205, and I need not repeat it here, as I do not think the dependence of the Syriac New 'Testament in this respect upon the syriac Old 'Testament has ever been seriously challenged. 'The evidence forces us, in fact, to regard the Old 'l'estament Peshitta as older than the Syriae New 'lestament, and as having been familiar to the translator of the latter.

'This at once accounts for a large number of peculiar forms, the origin of which does not here concern us, as it is sufficient to say that they were taken from the Old 'Testament. 'Thus 'Zion' is transliterated S'shyon, though the Greek is $\Sigma_{\iota} \omega \omega^{\prime}$ and the Hebrew צִי It is difficult to see how the syriae form ean have arisen, but it throws no direct light upon the geographical knowledge of the New Testament translator, as no doubt it was taken direct from the Old 'Testament in Syriac'.

some of the greater Geographical names may very well have been אורשילם Urishlem for Jerusalem, or ברית נדרeth Nahrin for Mesopotamia. What needs investigntion are the rarer names, names of persons that

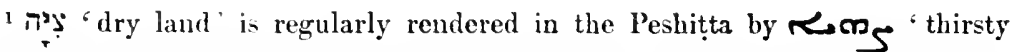
(regiou) $^{\prime}:$ it is, therefore, probable that ${ }^{\prime} \mathrm{S}^{\prime}$ was understood to mean Dry Tor, or some such signitication. 
do not appear to have been familiar to Syriac-speaking folk, and names of places for which we can hardly suppose that the natives of Edessa, or even of Antioch, could have had special appellations.

Once more we may remind ourselves of the nature of the processes gone through before a New Testament Semitic Proper Name appears in Syriac. It has been transliterated from Hebrew or Aramaic into Greek letters: the Syriac translator then takes this Greek transliteration, and either transliterates it into syriac letters, or decides on an appropriate Syriac equivalent. The latter process is not transliteration, but really a kind of translation: it may afford us historical information about the subject matter of the New 'Testament, but should not be used as a textual 'variant'. 'This simple caution is not always remembered, as an example will make clear. The name

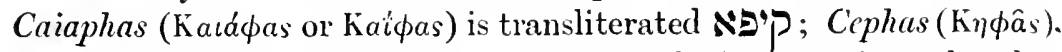
on the other hand, is באפט. At first sight it seems irregular that the Syriac equivalent to $K \eta \phi \hat{a}$ s should begin with $\supset$ instead of $p$. But what we have to recognize is that באפא is not a transliteration at all, but the Syriac for 'stone': the translator, or possibly Syriac: Church eustom, recognized that S. Peter's name was Simon Stone, and they called him, where necessary, by this appellative ${ }^{1}$.

When Westcott and Hort discuss the breathings to be assigned

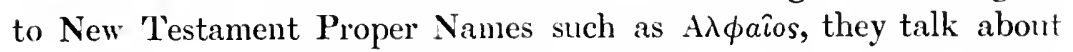
'the authority of the Syriac' (Introd., $\$ 408$ ). It is one of the chief' objects of this Paper to find out in what exactly the 'authority' of the Syriac consists. Is it, we ask, a real and continuous Palestinian tradition, or is it merely an achievement of learning, meritorious and interesting indeed, but not really authoritative? What had the Syriac translator to go by, when the Old Testament failed him, and when the context did not suggest (as it did in the case of S. l'eter's name) a practically certain solution?

Now it is true that there are a number of excellent transliterations. or identifications, whichever we like to call them, to be found in the Syriac versions. Simon the Camanaean (Kavavaîos) is rendered קנגיא, and so is properly distinguished from the Canaanite woman (Xavar'aía), who is בנעיתא. Tabitha and Talitha are sadly confused in Latin MSS.: in the syriac texts they are properly distinguished and intelligently spelt. Words referring to Jewish Parties, \&c.-Pharisees

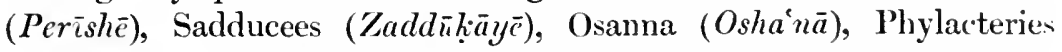
('Tephille $)$,- are given a syriac dress that is near enough to the

1 It is the same in Arabic, where S. Peter is commonly called سول |صفال 
current Jewish technical term to suggest some knowledge of Jewish conditions. Of the personal names, דנן for Annas, כנוא for

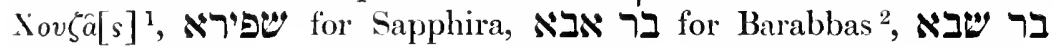

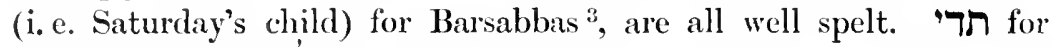
Thaddaeus and (Dalman 124) for sínas are recognized as Semitic names and spelt accordingly: it may be remarked in passing that the name of Simon Magus is spelt סיפון (Simon) in Syriac, as distinguished from Simon Peter and Simon the 'Tamner, who are given the same name as Simeon (Whimion) the Patriarch.

As is well known, the Syriac New 'Testament translates Xplorós by Mshilla, i.e. 'Messiah', wherever it occurs. 'I $\eta$ бov̂s becomes שוע' (pronounced Y'shu and $I$ sho'), which is the later Hebrew form of Joshua. 'The Peshițta always represents שוע שושוע', e. g. in Josh i 1, and it was no doubt the Syriac form of the name Joshua that determinert the spelling of the name for Jesus among Syriac-speaking Christians. It may here be mentioned that the controversial works of Ephraim syrus, now being edited by my friend Mr. C. W. Mitchell for the Text and Translation Society from a palimpsest in the British Museum, will shew that the Syriac-speaking Marcionites were not similarly influenced by the Old 'Testament, and that they transliterated 'I $\eta \sigma o \hat{v}$ s by is'.

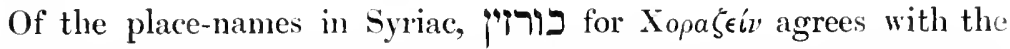
'Talmudic spelling: ב'ת פגא (Beth Phaggēe) for B $\eta \theta \phi a \gamma \eta$ is at least

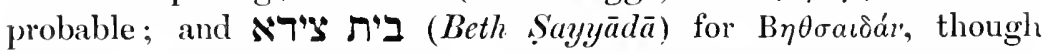
otherwise unattested, is possible. Other spellings, such as אירביא 'Arabia', which at first sight might seem inappropriate, are to be explained from the fact that such Greek words are not representations of Semitie names at all, but new Greek appellations. 'The "A $\rho \beta \beta \epsilon$ of Acts ii 11 are properly rendered by ערביא; but 'Apaßía is a mere geographical expression, invented by the Greeks and Romans, which is wisely transliterated by the Peslittta in Gal i 1\%, iv 25 without Semitic gutturals: S. Paul never meant us to infer that he passed three years among the Bedouins.

All these Syriac transliterations are intelligent, and a few of them really striking. At the same time it will be noticed that they are fairly straightforward; the best of them, such as those for Xopaseir.

1 Lk viii 3. The name is rertitied as Nabatean by an inscription at Madain Salil : see Expositor (5th Ser.) for February 1899, p. 1:1.

2 'The same patronymic was borne by the well-kuown Rabbi Hiya b. Abba.

3 The name of Mr. Satturday Davenant may occur to some English readers. More antique and oriental is Barhabbeshabba (i. e. Sunlay's child), one of the martyrs commemorated in the ancient Syriae Kalendar of 411. 
and Xov̧âs, simply follow the most ordinary rules of transliteration. We now have to consider one or two that I venture to characterize as strikingly bad.

The first impression of the modern scholar, accustomed to the methods of the Syro-Hexaplar and Harclean versions, is to regard with respect all Syriac transliterations that contain Semitic gutturals or Senitic sibilants, i. e. all words containing $\pi$ or $\boldsymbol{\nu}, \boldsymbol{\zeta}$ or $\boldsymbol{U}$. But this assumes that the Syriac word is meant for a real transliteration of the Greek; the case is quite different when there has been an attempt to find a Syriac equivalent for the Greek word. The clearest instance of what I mean is to be found in the Philoxenian (and Harclean) rendering of Abaddon in Apoc ix 11. Here we are definitely told that the word means 'destroying' in Greek, so that it is quite certain that the Old 'T'estament word אברון is intended. But the syriac equivalent is עברו, i. e. the translator has used the abs. sing. of roroitude'. 'This is universally recognized as being a translator's blunder and nothing more. At the same time it leads us to infer that the translator could have had no contact with any real tradition about the Jewish background to this Apocalypse.

But what Abaddon proves about the Apocalypse, Jairus proves for the Gospel in Syriac. 'The name 'látıpos occurs in the Greek Bible in Esth ii 5, where we read of .lapòoxaios ó rov 'Iacípov. When we look the passage up in the original Hebrew we find that Mordecai was the son of Jair (ריזידי). This evidence is really sufficient to establish both the original form of the name in the Gospel story and also its appropriateness there. Any name thought appropriate for an Israelite in a late and popular book like Esther might be expected to occur as the name of a personage mentioned in the Gospels ${ }^{1}$. Jairus ( $\mathrm{Mk}$ v $22, \mathrm{Lk}$ viii 41 ) should therefore have been ' $\mathbf{N}$ ' in the Syriac. But the name only occurs in the nominative, and the translator seems to have thought that the final -os was part of the root, and so he turns 'Iáєıos into ווארש' 2, as if it were one of those Jewish names beginning with - It. It is a bad blunder, an bad as turning Abaddon into 'servitude': the value of it for us is to make it unlikely that the Syriac translator of the Gospels was in touch with any real historical tradition about the names that occur in the course of the narrative.

'Jairus' does not stand alone. It would, indeed, be unfair to lay

I We may also record the existence of Eleazar b. Jair ('Ifipov), mentioned by Ionephus BJ ii 19.

2 Written Lia Lk viii 41 in S, a spelling also found in Gwilliam's 36 (Mk). 
very much stress on certain Names in the Genealogies, such as

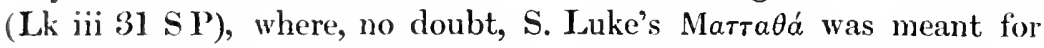

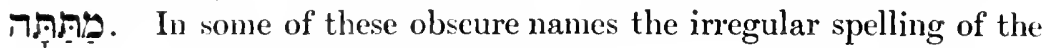
Syriac, particularly as preserved in S, appears to be due to a knowledge that the Greek spelling itself was quite irregular : instances are xas and 1 s in Lk iii $32 \mathrm{~S}$ for Boaz and Obed, corresponding, no doubt, to Booc and $\mid \omega \mathrm{BH}$. The 'course of Abia' in Lk i 5 is spelt אביא in the Peshițta, in agreement with the Greek and with 1 Chr xxiv 10, while $S$ has 1 in agreement with the Old Latin MSS. $c$ and $l$ *. In such cases as these we are dealing with transliterations rather than identifications, and at the same time the Syriac becomes for the nonce an authority for the spelling of the Greek word from which it is derived.

More significant than these are ' $\mathrm{N}$ J for Naiv (Lk vii 11) and

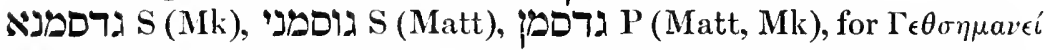
(Matt xxvi 36, Mk xiv 32) ${ }^{1}$. Whatever view may be held about the original meaning and spelling of these obscure names, it is clear that the Syriac translator had no private information, and that he guessed. and guessed badly, from the Greek letters in his exemplar. 'Nain', if it be connected with the place quoted in Neubauer 188, onght to have an 'ain in it (D'y), and the latter part of 'Gethsemane' is connected with the Hebrew for oil, and should have a $\mathscr{U}$, not a $\square$ (see Dalman 152). 'Gemnesaret' or 'Gennesar', again, is גנפר in Syriac: the'lalmudic form is ג'נינוסר, and it is natural to suppose that if the Syriac translator had derived his spelling of the name from living tradition it would have included a $\mathrm{a}$ between the $\mathrm{n}$ and the s.

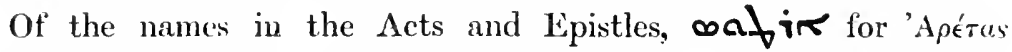
(2 Cor xi 32) is a very poor transliteration". The name of the Ethmarch must have been (Wright, CBM $704 \mathrm{~b}$ ), corresponding to the well-known Arabic names Märitha or el-Härith. In Acts ix 35 it is odd to find

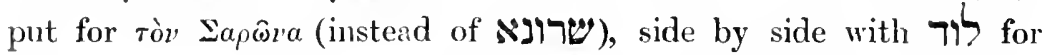

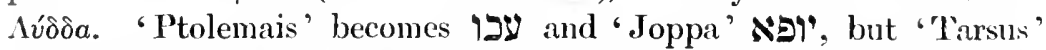
is merely transliterated טרסוס: possibly the pride of Roman citizenship had made 'Tarsus forget that in the Persian period it had spelt its name תר on its coins. 'Gaza' (Nid) and 'Azotus' (סוג) have Greek, not Semitic, forms of their names.

I have left out of consideration hitherto a number of the most interesting and controversial proper names in the Syriac New Testa-

1 'The oldest transmitted pronunciation is Gadsimann (see Guilliam, p. 171, note).

2 The Armenian of Ephraim ${ }^{\text {loc }}$ has Aret, with no sign of an initial guttural. 
ment, because we ought to examine them with reasonable ideas of the kind of rules or information from which the Syriac translator worked. So far as we have gone, I venture to think we have found nothing pointing to a special or extraordinary knowledge. 'The translator is familiar with the Old Testament in Syriac, and he has a good knowledge of ordinary geography, which he shews by giving the native names of the coast towns. But he does not always recognize Semitic names in their Greek dress, and there is no sign that he is specially familiar with the towns of Judaea or Galilee, or with the forms of Jewish names apart from those in the Old 'Testament.

I begin with the name Caiaphas, about the spelling of which the 'authority of the Syriac' has frequently been invoked '. This name is spelt Kaıфф৯c in most Greek MSS. in agreement with Josephus (Ant. xviii 2), but D and the Latins have Kalфac. The

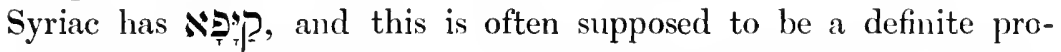
nouncement in farour of the first orer the second Greek reading. I doubt this: it is, of course, an indication of the way the Syriac translator thought the word was spelt in Palestinian Aramaic, but I do not think it gives us any information of the way the word was spelt in the Greek MS. from which the Syriac was translated. The Syriac translator thought $\mathrm{B} \eta \theta \sigma a \iota \delta a$ ( or B $\eta \theta \sigma a \iota \delta a v$ ) meant ' Fisherman's

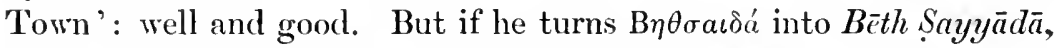
as he does, it is fairly obvious that his Kayyapha may stand for Kaı $\phi \hat{a}$ s as well as Katátias.

A somewhat similar conclusion appears to me to be indicated in the case of Bethabara and the Gergesenes, a couple of names which are very important in this connexion, as the forms found in the Old Syriac MSS. have been supposed to demonstrate that the Old Syriac Version itself was made later than Origen and under the influence of his exegesis ${ }^{2}$. It has been supposed that Origen himself introduced the name 'Gergesenes' (for Gadarenes or Gerasenes) as the name of the people among whom the Demoniac was healed, and also the name 'Bethabara' for Bethany beyond Jordan, where John was baptizing. Consequently, when we find גרגםיא in Mk v $1 \mathrm{~S}$ and in Joh i 28 S C, it is a plausible inference that the Old Syriac reading is founded upon Origen's conjectures ${ }^{3}$.

1 See e.g. Ency. Bibl. 172 , note 1.

2 The substance of the following discussion on these worls is taken from the present writer's article in the American Jommal of Biblical Literature xxvii 128-133, called 'Rergesu-a Reply'.

${ }^{s}$ It may be convenient to indicate here some textual facts which are assumed in the following discussion. (1) On general grounds there can be little doubt 
It seemed at first a confirmation of this theory that the name in Mk v 1 was written in Syriac with a D, not with a $\boldsymbol{E}$. Origen had not only expressed his opinion that the name of the city near which the swine had rushed into the sea was Gergesa, rather than Gadara or Gerasa: he went on to identify the people with the Girgashites of Gen xv 21. Mr. Raymond Clapp, to whom is due the credit of having called attention to the great importance of these names for our estimate of the date of the Old Syriac Version ', concludes that גרגםיא, the reading of $S$ in Mk v 1 , is a simple transcript of a Greek MS. which read $\Gamma \epsilon \rho \gamma \epsilon \sigma \eta \nu \omega \omega^{2}$, a reading which was itself the result of Origen's eonjecture. A little consideration will, however, shew that the Syriae form suggests the opposite conclusion, vi\%. that all that it tells us is that the translator identified 'the country of the [Gerasenes]' with 'the land of the Girgashites'. For, strange to say, the Old 'Testament Peshitta, in Gen xv 21 and elsewhere, represents the Hebrew

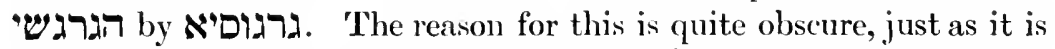

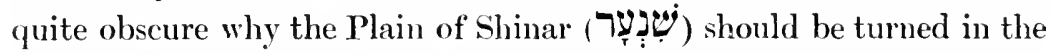
Peshitta into ספער. 'The Sinai Palimpsest, therefore, intends us to understand 'Girgashites' in Mk v 1, and the word should be pronounced Gargosāye".

With regard to 'Bethabara' in Joh i 28 the case is similar. The

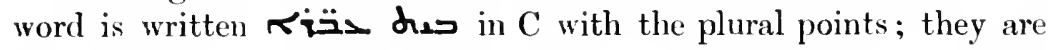
not legible in $\mathrm{S}$, but whether they are really absent or merely illegible in $\mathrm{S}$ their presence in $\mathrm{C}$ shews that the word was regarded as plural, and therefore as a significant appellation (like 'Overstrand ")

that Hort's conclusion is right, viz. the genuine reading of the Greek is 'Gadarenes' in Matt, but 'Gerasenes' in Mk and Lk. (2) In the Syriac, P has 'Gadarenes' everywhere; C has 'Gadarenes' in Lk (the only place where it is

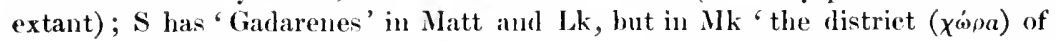
the G.' is rendered 'the land of the ארגסי'. (3) 'The renlering of the Diatessaron is not known from any early authority : naturally (iasca's Arabic implies 'Gadarenes', the reading of P'. (4) Syriac Versions appear to have had some tendency to introduce the name Galarene: Ahimelech of Gerar becomes Abimelech of i.d (Gen xx), and the Hagarenes of Ps lxxxiii 6 become r. These Gadarenes also meet $\mathrm{ns}$ in $1 \mathrm{Chr} x x v i \mathrm{i} 28 \mathrm{P}$. (5) 'Gadarenes' in Matt viii $28 \mathrm{~S}$ is simply a correct rendering of the Greek, and needs no further explanation; 'Gadarenes' in Lk viii $26,37 \mathrm{SC}$ may be a harmonization with Matt, or (more likely) an assimilation to the Diatessaron. It is the reading in Mk v I S, which has escaped harmonization, that needs explaining.

1 Journal of Biblical Literature xxvi 62-83. See also Baethgen's Evangelienfragmente (1885), p. 83.

2 The dropping of the $a$ in rem id presents no difficulty in the case of a MS. like S. For parallels, see Evangelion da-Mepharreshe ii 40 : see also Matt viii 28 in the margin of the Harclean Version. 
and not as a transliteration of a Greek word. In this interpretation the Syriac differs from Origen, who thought that $\mathrm{B} \eta \theta a \beta a \rho \hat{a}$ meant

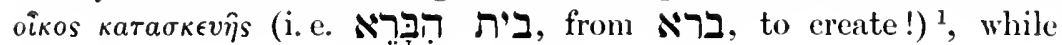

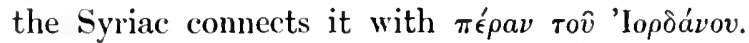

We find, then, that the Syriac agrees with Origen in thinking of the 'Girgashites' as the people who owned the Herd of Swine, and also in identifying the place where John baptized with a spot which may be spelt in Greek B $\eta \theta a \beta a \rho \hat{a}$. A couple of identifications such as these can hardly have been made independently, but we have further to go on and ask whether there is any justification for the common view, that these identifications were made for the first time by Origen.

Origen's Commentary on S. John, in which these identifications are found, is a bulky work, composed partly at Alexandria, and partly much later at Caesarea. In the former books, so far as they survive, the geographical interest is absent, though there are several pieces of Origen's characteristic lore about the Hebrew meanings of New Testament names ${ }^{2}$. But from Book vi onward, i.e. in the part written at Caesarea, Origen airs his knowledge of Palestine, and is quite ready to change the transmitted text of Scripture accordingly. What has happened in the interval? We could almost have guessed, even apart from our author's express statement, for we have all seen it in our friends and contemporaries. Origen has been on a Pilgrimage through the Holy Land, and he no longer needs information about the sites, for has he not seen them for himself?

At the same time, as I pointed out in the Paper already referred to, Origen does not himself claim to have discovered 'Bethabara' or 'Gergesa'. What he tells us is that 'they say that Bethabara ( $\tau \grave{a}$ $\mathrm{B} \eta \theta a \beta a \rho \hat{a})$ is shewon by the gorge of the Jordan, where they declare that John baptized' (Orig. in Joan. vi 40). Further on he mentions ' Gergesa, from which come the Girgashites (oi $\Gamma \epsilon \rho \gamma \epsilon \sigma a \hat{\imath} o l)$, an ancient city by what is now called the Lake of Tiberias, by which is a steep place close to the Lake, from which it is sheron that the Swine were (ast down by the demons' (Ibid. vi 41). 'This is what he learnt when he went on his pilgrimage, and in accordance with his geographical information he points out that Bethany is not beyond Jordan, and that neither Gerasa nor Gadara is situated on the Sea of Galilee.

The step that Origen took was to emend the Greek text of the Gospels in accordance with the local identifications. 'This is some-

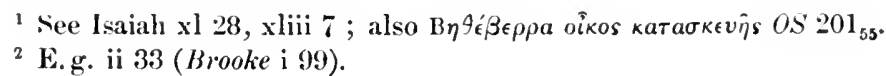


thing more than the translator of the Syriac Version can be proved to have done. His general aim was to find the proper Aramaic equivalent of the names, not to tell us with what letters the Greeks represented the Aramaic names. He does not care whether the

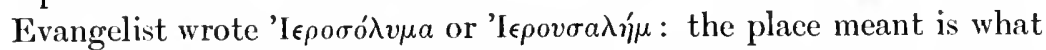
his countrymen called Urishlem, and he writes it so. No various

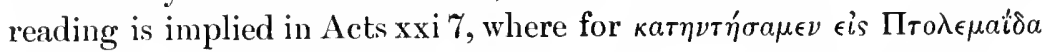
the Syriac has 'we came to Acre'. And if our translator was persuaded that the $\chi \omega \dot{\omega} \rho \tau \tau \hat{\omega} \nu \Gamma \epsilon \rho a \sigma \eta \nu \hat{\omega} \nu$ was the land of the Girgashites I do not think he would scruple to write it so.

The view $I$ am here advancing is that the agreement of the Old Syriac with Origen about the place-names Bethabara and Girgashites or Gergesenes comes not from the Old Syriac following Origen, but from both the Old Syriac and Origen following local identifications. I venture to think I have proved this conclusion not to be exeluded by the evidence. I have now to try and shew that it is not too artificial and improbable a theory to be believed.

In the first place, it seems to me fair to urge that any theory which makes the Old Syriac Version dependent upon Origen is in itself improbable. Apart from the evidence afforded, or seemed to be afforded, by these few place-names, the latest date assigned to the Old Syriac Version, as it stands in the Sinai Palimpsest, is about A.D. 200, more than a generation before Origen's commentary was written. In style, in manner, in tone, it is idiomatically Semitic, and far removed both from Origen's textual accuracy and his fanciful allegorizing. Further, the agreement with Origen is confined to geographical identifications; when it comes to the etymology of Semitic names there is a great difference. Origen was not really a profound linguist, and his ear for Semitic sounds seems to have been no better than that of most European tourists. 'The Syriac translator on the other hand was thoroughly skilled in Aramaic, his native language, and he discriminated between sounds which Origen confused. Palestimian Aramaic is, of course, different from the Syriac of Edessa, and the transeription of somnds in any language is a delicate matter, but the two dialects have the same gutturals and the same sibilants, and to a Semite they are not easily interchanged.

The independence of Origen and the Syriac is best represented by a Table: the right-hand column gives the transmitted Syriac text, while the middle column gives Origen's etymologies together with a conjectural restoration of the Semitic words intended by him. 
Origen.

Bethabara

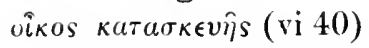

Syriac. בית הְָּּרָה

Bethania

oíкоs iтакойs (vi 4.0)

בית ענוה

Bethphage

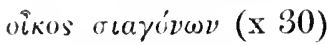

בית פבה

Jordan

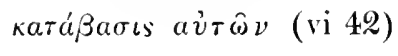

בית עברא

בית עניא - ביא

בית פגיא

'ורדנן

(i.e. no suffix)

Aenon

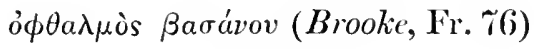

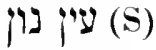

עין און

Salim

aùròs ò àvaßaîw (Ibid.)

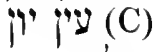

שלים

\section{של על (?)}

Origen's explanations are themselves in sad need of elucidation. Either he misheard certain Aramaic names, or he only heard them from Greek-speaking persons, and himself gave them his fantastic meanings. But if Origen were an authority at all for the Syriac translator, I cannot see why he should be trusted for place-identifications and deserted for derivations. Origen's derivation for Bethphage is especially interesting, for it is definitely Aramaic, yet it is different from that adopted by the Syriac Version.

The general inference I draw is that by Origen's time the identification of place-names in the Gospels had already begun to excite some interest among Palestinian Christians, themselves mainly a Greek-speaking body, not scientifically trained in the niceties of Aramaic pronumciation or grammar. At any rate, I venture to claim that the theory which makes the Syriac Versions depend upon Origen breaks down under investigation, and with it the theory that these Versions in any surviving form are later than Origen breaks down also.

The name of Bethphage, as already remarked, is spelt in the Syriac the same as in the lalmud. כ כ of Unripe ligs', and this is a far more likely rlerivation than oixos

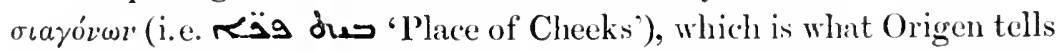
us it means. But Origen does not propose to change the spelling of

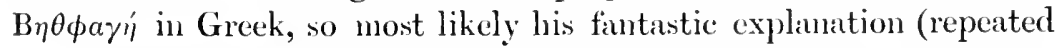
in the Onomastica) rests ultimately upon a mere error of the ear for Semitic sounds. About the identification of Bethphage there can be little dispute, though the exact site may be difficult to locate. It was a known place, and Origen tells us it was a rómos i $\epsilon_{i}$ arıkós, which looks 
as if he was really indebted to Jewish lore for his information, as the notices of Bethphage in the Talmud are comected with the virtual inelusion of the place in the Holy City for ecrtain purposes ${ }^{1}$.

The identification of Bethany is less certain, and therefore there is more donbt about the right pronunciation of the word. 'The Syriae has בית עניא, and this spelling also appear's to underlie Origen's oikos imaкoins. On the other hand, no place of this name is mentioned by ב'ת היני Jewish authorities, while there is mention of a place called which may be near the site of 'Bethany'. The question is complicated

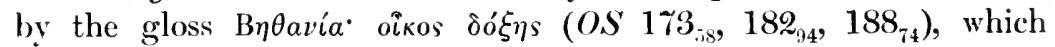
seems to indicate that a Christian tradition once existed that equated

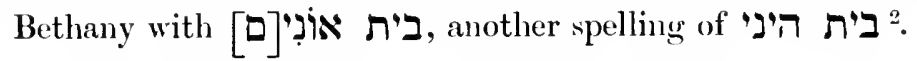

I do not think we are in a position to solve the question. Bethany was, no donbt, a small and unimportant hamlet: if it really was Beth Hini, then what we know about it is that it was destroyed three years before Jerusalem was taken by 'Titus ${ }^{3}$, and most likely all local knowledge of the place disappeared. When in the fourth century the victorious Christians built a great chureh over the reputed grave of Lazarus, the name Bethany, having no real root in the soil, withered away. The Lady Etheria, in the fifth century, knows of Bethania from her Bible, but on the spot she finds the place ealled Lasarium, and El-'A zariyeh it is called to this day. I venture to think, therefore, that the first Christian archaeologists had nothing to go on but the letters of $B H \theta-\Delta N I d$. It is hardly surprising that, with the analogy of Anathoth to help them, they should have thought that $\mathrm{aN}$ represented ני הינ rather than, after all, they may be right in not con-

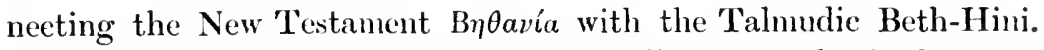
If the writer of the Second Gospel was really a Jerusalemite he must have known the true pronunciation of the name. Greek writing does not explain to us the initial consonant of ANId: it may equally well be $\boldsymbol{N}$ or $\pi$ or $\pi$ or $\boldsymbol{y}$. But the Gospel is good evidence that the following vowel really was ' $\mathrm{a}$ ' and not ' $\mathrm{i}$ ' or 'ai', as it ought to have been if 'בית הינ was intended. In short, the evidence suggests that the Syriac translator and the earliest Christian identifieators (represented by the Onomastica) had no real traditional evidence to go upon; at the same time it is equally insufficient to prove that the pronunciation they suggest is wrong ${ }^{4}$.

1 See the discussion in Neubaner $147 \mathrm{ff}$.

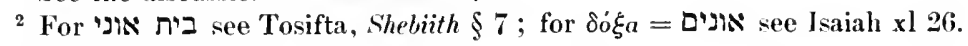

3 Baba Mezia 88 a.

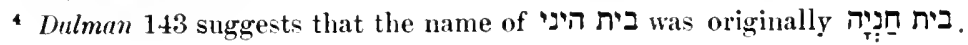


The spelling of four other place-names in the Syriac Gospels raise considerations of general interest. These are Gennesareth, Nazareth, Cana of Galilee and Bethesda.

Gennesareth is a fertile district in Galilee that sometimes gives its

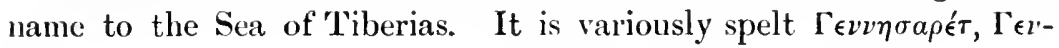
$\imath^{\prime} \eta \sigma a \rho^{\prime} \theta$, and $\Gamma \epsilon v v \eta \sigma a ́ \rho$, but our Syriac texts have גנסר without variation, vocalized Génessar in the Peshițta. No true Old Latin MS. has -eth or -et at the end of the word ${ }^{1}$.

Our Jewish authorities give us ג'גיסר in the Talmud in the 'Targums ${ }^{2}$, while Josephus and 1 Maccabees (xi 67) have $\Gamma \epsilon \nu v \eta a^{\prime} \rho$. The Syriac spelling, therefore, is vindicated as correct for an Aramaic document. But when we ask what is the genuine spelling in the Greek Gospels, the answer is not so easy. 'Gennesaret' is so familiar a word to us, that we realize with difficulty that it is confined to the non-western text of the Synoptic Gospels. For that very reason it is probably genuine there. 'The odd thing about the matter is that it is the Western authorities, including the Old Latin, that present the spelling which seems to be influenced either by local knowledge or knowledge of Josephus. It looks as if the longer form had altogether disappeared for a time from the text of the Gospels and then been reintroduced, possibly by Origen.

It would satisfy the general literary conditions if we supposed that Gennesaret belonged originally to Mark alone-a peculiar form belonging to the Evangelist who owes least to literary tradition. On this hypothesis Mark's 'Gennesaret ' was changed to 'Gennesar' by the more literary Evangelists Luke and Matthew. Harmonistic corruption would then cause the rarer form 'Gemesaret' to drop out of Mark, while at a later date it was re-introduced into the Greek text of all three Gospels. But I camnot say that the textual evidence at all points directly to the longer form being more characteristic of Mark than of the other Evangelists. 'Malmanutha' (Mk viii 10) is not a real parallel, for that word never found any acceptance in the other Gospels. A nearer parallel may possibly be found in 'Nazareth'.

The name Nazareth is conneeted with more than one insoluble problem. In the Greek Gospels the name is spelt sometimes Najapét

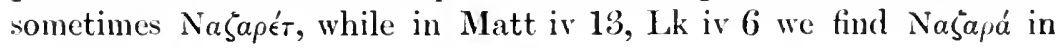

I Mk vi $53 a$ is not really an exception : it has genneza|retcumexis|sentdenajui. The $e t$ is wanted to begin ver. 54 , so that the archetype must have read Gennezur ${ }^{54}$ et ...

2 Corresponding to the Biblical בנרת, e. Num xxxiv 11, Jos riii 27. 
the best authorities, both Greek and Latin. Neither of these verses is taken from Mark, while they are historieally parallel to one another. It is, therefore, a legitimate inference that the statement of our Lord's settlement at this town was taken by Matthew and by Luke from $Q$, the non-Markan source, that the name of the town was given in Q, and that it was there spelt Nasapá. We have, then, Nazaret (or Nasareth) for Mark and Nazara for Q.

The Syriac texts, without exception, have נצרת, vocalized Nässrath

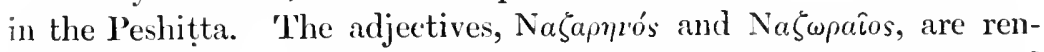
dered by נצריא. In accordance with this identification, the accepted site of 'Nazareth' is called النLاص to-day, and the Moslems call a Christian Naşrāne (pl. Nașāra).

Nevertheless, there are difficulties in this identification. 'The first and gravest is the $:$ in 'Nazarene'. 'The fact is, that in hardly any other instance does Greek $\zeta$ stand for Semitic $\boldsymbol{\zeta}^{\prime}$. We are aceustomed to the representation of $\mathbf{\xi}$ by $\approx$ in English, because it is done in the Authorized Version of the Old 'Testament. But this $z$ is really "made in Germany': it is the German is, to be pronounced like $t s$, and it was first used by the German Reuchlin, the friend of Erasmus, to imitate the sound which his Jewish teachers used. Before Reuchlin's time the universal transliteration of $\boldsymbol{s}$ was simple $s$, both in Greek and in Latin. The difference between the ancient and the Renaissance system is best illustrated to English people by the name of the city of David, which is 'Cion' in the Old 'Testament, but 'Sion' in the New 'Testament and in the Prayer Book. Now whether we accept the

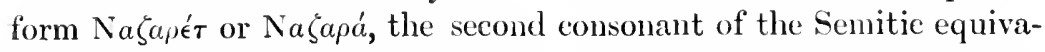
lent ought to be zain (i) not sade (\$). Or putting it the other way, if the name of the town were נצרת, or if the Jews were right in calling Christians נוֹצִרִים ('Taan. 276), then the name of the town should

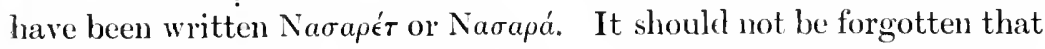
s) Greek Gospels are some two generations earlier than any surviving monument of Semitic Christianity. According to the Acts, Christians were once called members of the sect of the Nazoraeans ( $\tau \hat{\omega} \nu$ Na $\zeta_{\omega} \omega a^{\prime} \omega \nu$ ), and we know that in later times a Semitie-speaking sect of Christians was called by this name. Unfortunately we do not know how these persons wrote their nane in their own Aramaic vernacular. The Talmudic passage quoted above (Gemara of R. Johanan) is later than the Old Syriac Version. 'Tertullian's reference to Jews calling Christians Nazaraci or Nazarcni is comected by that Father with Lam iv 7 and the Nasirites, i. e. with the בירים.

${ }^{1}$ See $A_{\text {ppendix }}$ III for details. 
But, it may be said, at any rate there is the town Nazareth; how is that spelt? Here comes in the importance of 10r. Cheyne's statement that 'no such town as Nazareth is mentioned in the Old 'Iestament, in Josephus, or in the 'Ialmud' (Ency. Bibl. 3360) '.

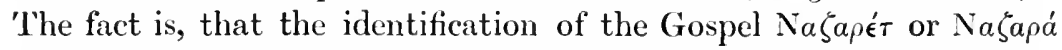
with a place spelt of Bethany with Bethabara, or Gerasenes with Girgashites. It is a piece of early Christian archaeology, rather than of primitive tradition.

All attempt has been made to regard Nazara or Nazareth as a name for Galilee, but it seems to be destitute of any ancient evidence, and it certainly contradicts the Gospels, which speak of Nazareth as a town (Matt ii 23, Lk iv 99). The one thing that is told us is that it was situated on a hill ( $\mathrm{Lk}$ iv 29 ), which is true of half the villages of Palestine. If you leave out of consideration the narrative of the address at the opening of the Ministry in the synagogue at 'Nazara', a narrative peculiar to $\mathrm{S}$. Luke, and apparently composed by him out of MK vi 1-5 together with some very probably genuine sayings of our Lord which he took from another source, there is nothing whatever in the New 'Testament to individualize Nazareth at all beyond the mere letters of its name.

There are, it must be noticed, two passages where the name of Nazareth might have been expected, where nevertheless it does not occur. 'The first is Mk vi 1-6, which relates the unsuccessful ministry

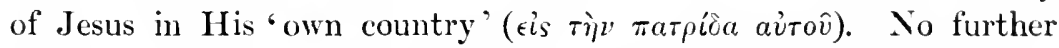
name is mentioned, though we hear of the Synagogue, and of the villages round about. 'The other is $\mathrm{Lk} \times 13-15=$ Matt xi 20-24, i. e. the 'woes' on Chorazin, Bethsaidan and Kapharnaum. Of these places, Kaphamaum is the actual centre of the Galilean preaching, Bethsaidan ( said in the Fourth Gospel to be the town of Andrew and Peter) is the place of refuge just outside the domains of Herod Antipas, and wonderful deeds are actually recorded that took place in its immediate neighbourhood. But nothing is recorded in the Gospels about work or preaching in Chorazin, while the rejection of Jesus by His fellow-townsmen would have made 'Nazareth' quite appropriate in this passage. No place in Galilee, indeed, would be so appropriate.

With some misgivings, I venture to suggest that the name - Nazareth', like that of 'Dalmanutha' and 'Boanerges', may have

1 'The nearest thing is Beth Lehem Șerieh (בית לחם Sרייה) in Hegilla i 1, on Josh xix 15. See Neubauer $190 \mathrm{f}$. 
arisen from a literary error. I mean this, that we ought to consider the possibility that the city of Joseph and Mary, the marpis of Jesus, was Chorazin.

I do not suppose the adjective 'Nazarene' to have been originally derived from Chorazin. 'This adjective, in the two forms NaSapqrós

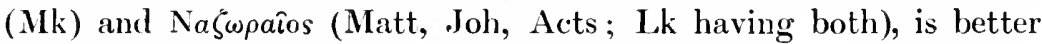
attested than the name of the town from which it is commonly derived. It is difficult not to think that Jesus was called 'the Nazarene', or 'the Nazoraean': what is doubtful is the meaning of the term. It is not easy to understand the form Naלwpaîs in any (ase, but the difficulty is greater if we have to make it an adjective denoting an inhabitant of Nazara or Nazareth.

After considering the matter from various points of view, it seems to me most probable that the word is really connected with 7 'is and the vow of the Nazirites. Of course Jesus was not a legal Nazirite, whatever John the Baptist may have been, for He drank wine. 'That He did not scruple to touch an apparently dead body proves nothing, for the daughter of Jairus came to life again. Moreover the saying 'Let the dead bury their dead' aetually expresses an integral part of the Nazirite's enforced freedom from certain social obligations. Is it not possible that 'Nazoraean' was a nickname? It might conceivably mean 'this odd sort of Nazarite'-one who calls for repentance, and yet eats and drinks like other folk (Matt xi 19, Lk vii 34). The true origin of nicknames is easily lost, and it may have been supposed that the name referred to some place in Galilee. It should be noticed that most of the consonants of XopazeIN reappear in reverse order in $N \Delta z \Delta p \in \theta$.

It is a desperate conjecture, and I would not make it, were it not that the ordinary view of Nazareth seems to me wholly unproved and unsatisfactory. And the most unproved and least satisfaetory part of the ordinary view is that part of it which is attested by the Syriac Versions, whereby the $:$ is made to represent a Semitic $\$.

Canc of Galilee is mentioned four times in the Fourth Gospel ${ }^{1}$, and has been variously identified. But in the Syriac it becomes resfo, and this in the eonstant tradition of the Syriac Vulgate is vocalized $\underline{k} \bar{a} t n^{-2}$. 'There is no variation in the Greek, which is, moreover, treated by the Evangelist as fem. sing. ( $\epsilon i s$ rìv Kavá, Joh iv 46).

1 Joh ii 1,11 ; iv 46 ; xxi 2 .

2 'This is the vocalization it would have if it were the emphatic plural of a participle active, and accorlingly some MSs. of the Peshițta spell it مif with the plural points. 
'This change of Kavá into Käạtnē caunot be explained on palaeographical or linguistic grounds: the words are really as distinct as Ptolemais and Acre, and I think we must infer that the Syriac word represents a deliberate geographical identification.

Unfortunately, neither this identification nor the ordinary one can be made out with certainty. The marriage-throne of the bride and bridegroom at 'Cana', three miles from Diocaesarea, on which in the vear 5\%0 or thereabonts Antoninus of Placentia scratched his family name ', has disappeared, and the Syriac $K \bar{a} ! n \bar{c}$ is almost equally hard to find. Katana near Damascus is too far away, and possibly the place meant is ת'sטp, the Biblical Kiattath (Neubaner 189). But this hardly explains the odd vocalization.

IVe are not, however, directly concerned with the actual site. 'The important thing in our investigation is that the variation between the name of 'Cana of Galilee' as written in Greek and as represented in Syriac suggests a geographical identification. Such an identification could hardly have been made by a Christian scholar staying at home in Edessa, and we must infer that the translator himself, or the source from which he derived his geographical theories, must have been a Palestine Pilgrim.

Round the name of Bethesda many controversics have raged, both topographical and textual. The latest and certainly one of the most interesting studies of the questions regarding it is that by Dr. Rendel Harris in his book called Side-Lights on New Testament Research, pp. 36-51 and $70-76 \%$ I shall not attempt to touch upon all the points raised, except in so far as they relate to the subject immediately before us, which is the 'authority' of the Syriac Biblical tradition. 'The 'Bethesda' question is twofold: there is a doubt concerning the site, and a doubt concerning the name. As for the site, excavations near the church of S. Anne in the north-east corner of Jerusalem, not far from where our topographical authorities place the Sheep-gate mentioned by Nehemiah, have brought to light the Pool which in the early days of Christian

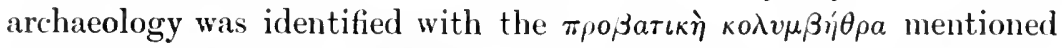
in Joh v 2 and in the Onomastica. It was this Pool that was seen by the Bordeaux Pilgrim in A. D. 333, and in certain other ways it satisfies the data very well. But this lool is in the quarter of Jerusalem called Bezetha by Josephus, and as several very ancient

\footnotetext{
1 Itimera Sancta 161: in ipso accubitı, ubi ego indignus uomina parentum meorum scripsi.

2 Angus Lectures for 1908.
} 


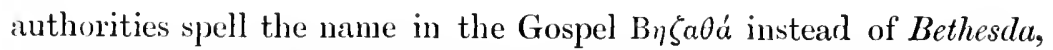

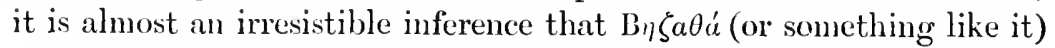
is the true reading. There is some doubt about the spelling of Bezetha in Josephus: a more accurate expression, therefore, for our conclusion will be that Josephus and the Evangelist intend to give the same name.

The most puzzling part of the evidence is that Josephus seems to tell us that Bezetha means Kainopolis or New 'Town '. This is really quite impossible. The best attested spelling is $\mathrm{B} \epsilon \zeta \epsilon \theta$ á. Now $\zeta$ between two vowels must stand for Semitic zain, and there is no $;$ in 'New' or 'llown', whether we try Hebrew or Aramaic. Beth $H a(d)$ tha has been suggested, but this does not mean 'New 'lown'. It does not even mean 'New House' or "The New House ; if it means anything it means 'The House of the New Man'. Beth, literally 'House', is used in the construct state before nouns to mean 'The Place of', as in Beth Pliagge', i. e. 'The Place of Unripe Figs'. But it is not so used before ordinary adjectives. Neither in Aramaic nor in English is New House synonymous with New Town. And when we come to the actual words of Josephus we find that he does

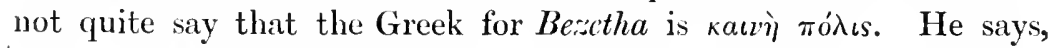

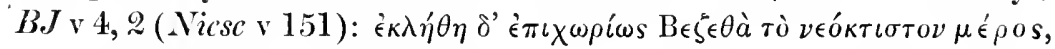

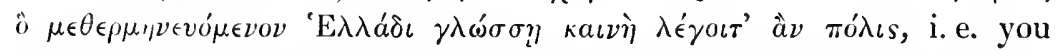
might translate it so, but perhaps another phrase would be better. In $B J$ ii 19, 4 he seems to distinguish between 'Bezetha' and his

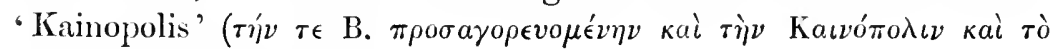

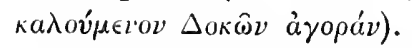

Professor Dalman (Gram., p. 115) connects the name with $\mathrm{B} \eta \zeta^{\prime} \theta$ (1 Mace vii 19), a place also spelt B $\eta \theta \zeta a i \theta$, Begeth, and Bethrecha, and he supposes the name to mean 'Place of Olives' (בית זיתא). But it seems to me, on the whole, best to take a hint from a previous sentence to the above-quoted passage from the 'Jewish War'. Josephus says, describing the hills of Jerusalem (Ibid. = Niese v 149):

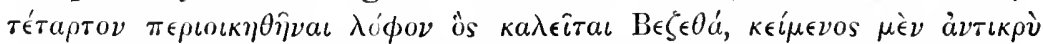

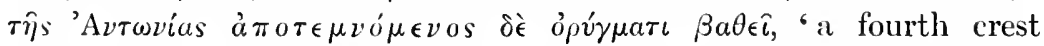
which is called Bcrstha, situated opposite Antonia and cut off from it by a deep moat" ". But does not this suggest a derivation? Is

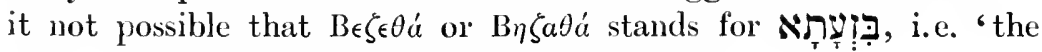
bits cut off', or possibly

' $B J$ ii 19, $4 ; B J \vee 4,2$ (= Niese v 151).

2 There was a great pit or tank (фpéap) in 'Bezeth', where Bacchides flung his victims. 
But whether we take this, or regard Bezcth as the old name of an outlying village, now become part of the town, or suppose that the name means 'Place of Olives', we do not in any case come to Bethesda. 'This, the most familiar form of the name to us, is with one significant exception not supported in any of the authorities by which modern critical editors are generally influenced. It is not in the Onomastica, which have B $\eta \zeta a \theta a$ in Greek and Bethsaida in Latin. It is not in $\mathrm{B}$ ( $\mathrm{B} \eta \theta \sigma a \iota \delta a)$, in $\aleph(\mathrm{B} \eta \theta \zeta a \theta a)$, in $\mathrm{D}(\mathrm{B} \in \lambda \xi \epsilon \theta a)$, in the genuine Old Latin (Besatha, Betzata, Belsatha, Betsetha), or the Vulgate (Bethsaida). 'The Egyptian versions, also, with the text of the Harclean and the Ethiopic, have 'Bethsaida', spelt like the 'city of Andrew and Peter'.

The supporters of $B \eta \theta \epsilon \sigma \delta \alpha$ are the vast majority of Greek MSS. (including, of course, $\mathrm{A}$ and $\mathrm{C}$ ), the Gothicizing revised Latin texts $f$ and $q$, and all the Syriac versions, except the text of the Harclean. It is also in the Armenian, where the spelling (Beth licsda) makes it pretty certain that it has been derived from a Syriac source.

For 'Bethesda' are the Byzantine tradition and 'the authority of the Syriac'; against 'Bethesda' are the ancient Versions (except the Syriac), local tradition, and the most ancient and trusted Greek MSS.

Such a division of the evidence is not only unfavourable to Bethesda; it makes it very likely that the Old Syriac Version, which is the one really ancient authority that supports this reading, is also the source of it. We are dealing with probabilities, and by the nature of the case we cannot hope to do more than frame a hypothesis, which will cover the facts of the case and be consistent with the phenomena of other various readings and unlikely forms of Proper Names. $\mathrm{My}$ hypothesis, then, is that $B \eta \zeta a \theta \dot{a}$ was the form written by the

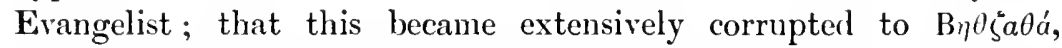
B $\eta \delta \zeta a \theta a ́$, \&c., and also widely assimilated to 'Bethsaida'. 'The Syriac translator, on the other hand, whatever of these forms may have been before his eyes, thought that 'House of Mercy' was not far off, and so wrote Beth Hesda. The Martyr Lucian, or whoever else is the real foster-father of the Antiochian-Byzantine text ${ }^{1}$, may very likely have had 'Bethsaida' in the text that lay before him: this was a manifest geographical blunder and needed correction, and the correction that was chosen was derived from the Syriac tradition.

'The whole question is, in certain ways, parallel to the question of 'Nazareth'. In both cases we have a current tradition now in vogue about the names, a tradition which is unsatisfactory in the light

1 The text called $K$ by von Soden. 
of the earliest evidence. In the case of Nazareth it is the selection of a site, in the case of Bethesda it is the form of a name. In both cases by far the oldest witness to the unsatisfactory current tradition is the ancient Syriac Version. I do not believe these Syriac names have any more 'authority' than Joārāsh for Jairus, or K Käṭne for Cana; the only difference is that the former pair found favour at the end of the fourth century among the Greeks and the latter pair did not.

It will be convenient to notice here certain Syriac forms of Proper Names that for various reasons need some elucidation.

1. 'The Elamites of Acts ii 9 are rendered $($ Alanäyeje) in 1 '. 'This is not an irregular transliteration of 'E $\lambda$ c $\mu \in \hat{\epsilon} \tau a$, but means the Alans, a barbarous people mentioned by Pliny (vi 26) in connexion with the Kurds and by the Dialogue De Fato (w 3) in connexion with the regions north of Pontus. The name of the Elamites was no doubt taken by S. Luke from the Old Testament, but a Mesopotamian translator would know that they were extinct as the Druids, and so he chose a more modern name from the same sort of region as an equivalent. In exactly the same spirit De Sacy's Arabic translates the 'Parthians' by

2. Bar-Jesus, the name of the Magus in Acts xiii 6, is variously spelt in important Westem texts, so that the original reading is somewhat doubtful. In P בר שומא (Barshuma) is given as an equivalent. The meaning of Barshuma is not known: what is known is that it was an old family name in Edessa, where it appears on the preChristian grave of עיו ברת ברשומא (i.e. 'Stella, daughter of Barshuma') $)^{1}$. I do not suppose we can reconstruct the Greek word which suggested Barshuma to the Syriac translator, any more than

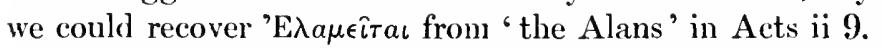

3. Matthias in Acts i 23, 26 is transliterated מת'א in P. So far as $I$ know, there is no variation in the name in Greek or Latin,

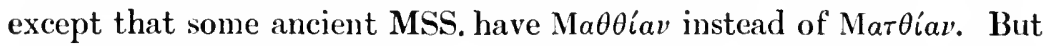
in Syriac the case is different. Aphraates 150 (Demonstr. iv 6) calls him 'תולמ, and this name is substituted for 'Matthias' wherever it occurs in the Syriac Version of Eusebius's History. It is evident that

1 ZIDMG xxxvi 164. I take this opportunity of suggesting that the difficult worl in line 3, real Rais by Sachau, may be an ill-cut Risor. The first four lines will then run: (1) 'I, 'Iu bath Barshuma, (2) lave male for myself this tomb. (3) I beg of thee, whoever else enters (4) here, not to move my bones and the sarcophagus.' I assume that עיותא (Job ix 9), the name of a certain star or Constellation. 
this is no mere palaeographical error, but that the Old Syriac Version of the Acts must have had " in Josephus (Ant. xx 1), and is, of course, the second part of the name Bartholomew '; An obscure name Samuel, but תול תומ' nothing more than l'tolemy in a Semitic disguise (see Levy, Neu-Hebr. Dict., s. v.). Why the Old Syriac of Acts should have represented Matthias by this name cannot now be ascertained.

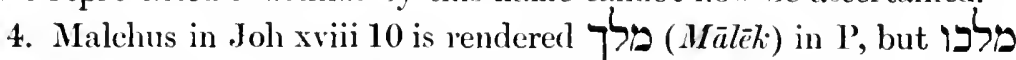
(? Maleku) in S. 'The word occurs in $S$ at the end of a line, so that it is not quite certain that an may not be lost in the margin: in that case $S$ would present a mere commonplace transliteration of Má $\lambda x o s$. But as the name appears to be treated as a Semitic one in $\mathrm{P}$, it is more likely that מלכו מל is the true reading, in which case we have an interesting parallel to 'Gashmu the Arabian', mentioned

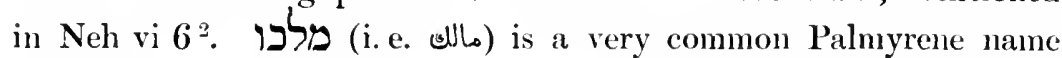
(Cook, Aramaic Glossary, p. 73, where, however, 'vol. $\gamma$ ' is a misprint for 'vol. 6', and sל is a woman's name).

5. Finally, as bearing upon the general sociological equipment of the Syriac translator, it should be noticed that the technical .Jewish

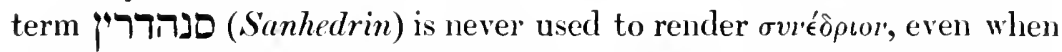
it might have been not inappropriate. In Matt x $17 \mathrm{SP}$ the technical Jewish term for the local Jewish Court is correctly given (בית רינא,

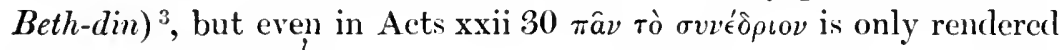
כלה כנשיא ררשיהן, i.e. 'all the assembly of their Heads'. I imagine the translator was only acquainted with the provincial Judaism of Upper Mesopotamia. 'Phylacteries' and 'Beth-dins' hc. knew, but the parts of the Jewish organization that came to an end with the Destruction of Jerusalem were as unfamiliar to him as to the rest of the Gentile world.

It is now time to sum up the main results of these scattered observations. I shall attempt to do so in a series of propositions.

(1) The translator of the Syriac Version aimed at giving the vernacular equivalent of the New Testament Proper Names, rather. than a transliteration of the Greek.

Examples: Acre for P'tolemais, Alans for Elamites.

1 In Matt viii 3 tholomeus occurs in " for Bartholomew.

2 No doubt ג' בُشَ' whence king derived the spelling rocєs'.

s 'The Syriac should be vocalized Beth din', with Gwillian's Ylas. 3, not Beth dayyane (i. e. 'Place of the judges'). 
(2) Wherever possible, the forms of the Names in the Syriat New Testament are assimilated to those in the Syriac Old Testament (Peshitta), which is earlier and normative for the Syriac New Testament.

Examples: Sehyōn for Sion, I c shue for Jesus.

(3) When the Old Testament failed, the Syriac is sometimes demonstrably wrong.

Example: Yoāräsh for Jairus.

(4) A connexion between the Syriac translator and Origen is to benoted, but it is by way of agreement in identification combined with disagrecment in etymology.

Examples: Bethabara and Bethphage.

(5) The connexion is to be explained by the rise of local Palestinian Christian traditions, fostered by the rise of Christian pilgrimage.

Examples: 'Gergesenes' and again Bethabara.

(6) Some Syriac identifications never influenced non-Syriac Christian tradition. This demonstrates the existence of a certain independence in the Syriac identifications.

Example: Kă $\bar{t} n \bar{e}$ for Cana.

(7) In other cases the Syriac identification is the oldest evidence for the modern and incorrect theory, and in some cases may have been the parent of that theory.

Examples: Näsrath for Nazareth, Bethliescla for Bezatha.

(8) Now that a direct dependence of the Syriac New Testament upon Origen is excluded we are free to date the work in conformity with all the other indications, i.e. in the last quarter of the second century A.1). It is thus the earliest surviving momument of the reviving interest which Christians were beginning to take in the Holy Places. 'This lessens its value for textual criticism, as the translator becomes, to a certain extent, a critic rather than a witness. When minutely examined, the Syriac Version, even in its oldest form, shews, like all other monmments of Christianity, the great chasm that separates the second-century Christian Church from Palestinian life before the Destruction of Jerusalem. The only bridge aeross this great chasm is the Greek text of the New Testament itself. Naturally I do not wish to deny the continuity of Catholicism with the first preaching of the Christian Gospel, but the continuity with the Fathers of old time to which the Catholic Church of the second century justly attached so much weight was connected with ideas and not with tangible antiquities. It is possible for theologians to have very different notions of the 'deposit' which 'Timothy was charged so carcfully to guard, but quite certainly it did not include 
any theory as to the site of Nazareth. For such things we are driven back to the words of the Greek 'Testament, and the Semitic consonants of the Syriac Version bear witness to no geographical or linguistic tradition that goes behind this.

\section{F. C. BURKIT'I.}

\section{APPENDICES}

\section{Alphates, Agabus, Hebrew.}

The three names Alphacus, Agabus, and Hebrez, are best treated together in the form of a Note to Westcott and Hort's well-known Introduction $\$ 408$, a paragraph explaining and defending the smooth and rough breathings adopted by them in their edition of the Greck text of the New Testament. They say:-

'In proper names transliterated from the Hebrew or Aranlaic we have . . exactly followed the Hebrew or Aramaic spelling, expressing $\boldsymbol{N}$ and $\boldsymbol{y}$ by the smooth breathing, and $\boldsymbol{\pi}$ and $\boldsymbol{\Pi}$ by the rough breathing.

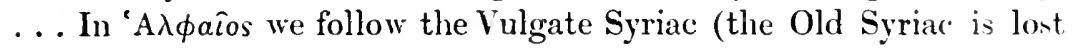
in the four places where the name occurs), which agrees with what the best modern authorities consider to be the Aramaic original. We have also in the text accepted the anthority of the Syriac for

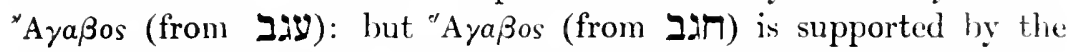
existence of a Hagab in Ezr ii $45 \mathrm{f}$.; Neh vii 48 . In like mamer

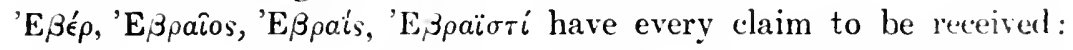
indeed, the complete displacement of Ebraeus and Ebrew by Hebraeus and Hebrew is comparatively modern.'

'The fame of Hort's Introduction is assured, but some evil genius must have possessed him when he compiled this paragraph. It contains highly doubtful opinions stated as if they were axioms, and one or two downight blunders. As however it quite accurately represents the actual practice followed in all editions of 'W.-H.', it seems worth while to point out the facts.

I never could understand why $\boldsymbol{y}$ should have a Greek 'smooth' breathing, while $\pi$ and $\Pi$ are to be indiscriminately represented by. the 'rough'. The Greek breathingrs do not exactly correspond to any Semitic letter, but they do exactly correspond to the mles 
observed about aspirating or not aspirating the preceding consonant, and these rules are our only safe guide.

'Io take the case of Hebrew first. Here mediaeval Latin and English spellings tell us nothing at all, and unfortunately there is no

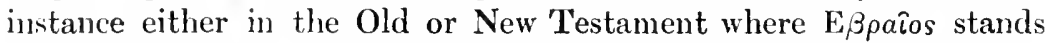
immediately after a mutable consonant. But Westcott and Hort appear to have forgotten all about the 'Gospel according to the

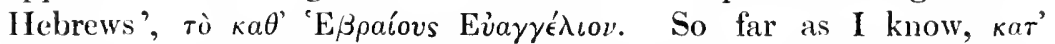

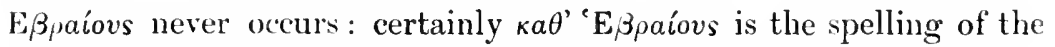
MSS. in Eusebius $H E$ iii 25,27 , iv 22, and in Origen in Joan. ii 12. 'This, surely, is decisive evidence in favour of the rough breathing ?

Agabus has been equally unlucky. I do not know how Westcott and Hort eame to think that this name began in Syriae with $y$, or why the statement has been so often repeated, e.g. by Blass in his edition of the Acts, the fact being that the name in Syriac is written

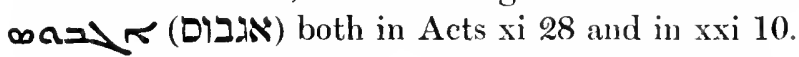

since the name ends in of, i.e. since the Greek termination is transliterated into Syriac, we must infer that the Syriac translator did not regard the name as recognizably Semitic; in other words, he gives us no opinion as to its derivation. $\infty$ a) $\%$ is simply a transliteration of $\triangle \Gamma \mathrm{ABOc}$, and tells us nothing as to the breathing we ought to prefix to the word. If on quite other grounds we think А $\triangle$ В may prefix a rough breathing, but the Syriac evidence tells us nothing except that our proposed derivation was not obvious in ancient times.

'Ihe decision between Alphaeus and Halphaeus is less clear. Here the Syriac versions, now reinforced by the Sinai Palimpsest, have IIalpai (דלכ). 'This really does imply that the word is recognized as Semitic, not only because of the initial guttural, but also because the Greek termination is dropped. It may further be remarked that

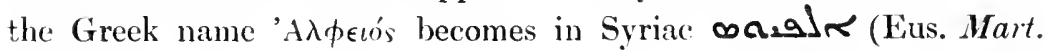
Palest. i).

'The name Halpai does not certainly occur in Jewish sources. Dalinan (p. 142) cites "פ97 from j. Kidd. $58 \mathrm{~d}$, but this is not the name of a Rabbi. The word seems to mean 'controversialist' (خلافي). Moreover, in b. Taan. 21 a it appears as Nיאיא' However, as there is no sign of a various reading 'A $\lambda \phi \epsilon$ ós in the New Testament, the 'authority of the Syriac' may in this case stand, quantum valcat, and we may continue to write 'A A $\phi$ aîos.

1 Under the influence of Westcott and Hort the smooth breathing has been used for 'E $\beta$ pains in the Cambridge LXX and the Oxford Concordance to the LXX ! 


\section{Caplinaum, Caphalisaun.}

IT is well known that the Textus Receptus of the New 'Testament

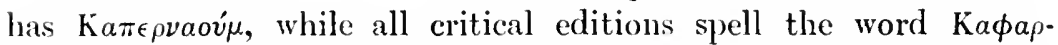
r'aoúp. These names are the subject of a study by Professor E. Nestle in a I'estschrift for 'Theodor Zahn (Leipzig, 1908, pp. 251-270), which like all Nestle's work is packed full of curious and recondite informa-

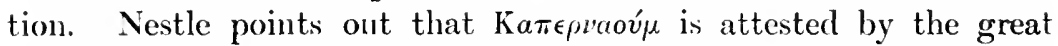
mass of Greek MSS., Kaфapvaoú $\mu$ by $\aleph \mathrm{BD}$, and also by practically all the Versions. 'The Syriac has pasesia, and Nestle conjectures that the two forms arose from different pronmeiations of this. It is well known that the East Syrians pronounced $\unlhd$ hard (i.e. hard for Semites): if then כפר was really a monosyllabic form, and if the East syrians pronounced the word Kapr, then $\mathrm{K} a \pi \epsilon \mathrm{r}^{\prime}$ aov $\mu$ might have arisen from the East Syrian form.

Nestle is quite right in saying that the ancient syriac Versions camnot be claimed as witnesses to decide between $\pi$ and $\phi$, as they use 9 indifferently for both. But the other part, equally essential, of his ingenious theory breaks down on investigation. The East Syrian pronunciation of the name is or Kphar Nâham, not Kapr $\boldsymbol{N}$. 'This is not only the reading of the Urmi editions and those founded upon them: I have ascertained that sases the reading of the 'Nestorian Masora', i. e. B.M. Add. 12138, one of the most careful and aecurate MSS. ever written. lurther, the place called כִכְּר העמונה in Josh xviii 24 is called in the Urmi Bible دفํ. It is, therefore, evident that the

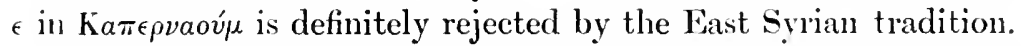

'This brings the matter back where it was. But on general grounds it was not likely that the solution of this curious problem would

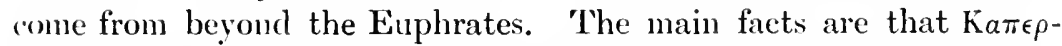
is attested by what Dr. Hort calls the Antiochian text, while Kapapis attested by all others. It is a natural inference that the pronunciation of the Greek-speaking population of the Antiochian district may have something to do with the matter. Dr. Nestle yuotes 'Theodoret for' $\mathrm{K} a \pi \epsilon \rho \sigma a v \hat{a}$, and 'Theodoret is certainly a witness for fourth to fifth century Antiochian fashions, which is exactly what is wanted. Using then 'Syrian' in the sense used by Hort, i. e. not for that which is Aramaic, but for what is characteristic of the Greek-speaking district of which Antioch was the capital, we may after all agree with Nestle, that in the prevalence of the spelling 


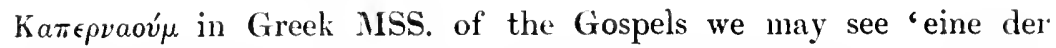
stärksten Bestätigungen der Theorie von Westcott-Hort, dass der Textus receptus die Frucht einer syrischen Rezension ist'.

\section{Gresi Z For Hebrew $\mathbf{~}$.}

'THE Greeks habitually represented Semitic $\boldsymbol{\zeta}$ by simple $\sigma$. Besides words like $\Sigma_{\iota}(\hat{v} v$ for $\mathbf{j}$, צhich is after all an exclusively Biblical and

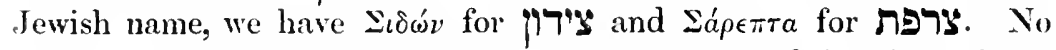
rule, however, is without apparent exceptions, and in view of the importance of the statement made above (p. 16) that in hardly any instance Greek $\zeta$ stands for Semitic $\boldsymbol{\xi}$, it is worth while to examine the names in the Greek Bible (besides 'Nazareth') in which $\zeta$ is apparently so used.

In all there appear to be ten. 'Taking them in their most familiar English form and in the order of the English alphabet, we have

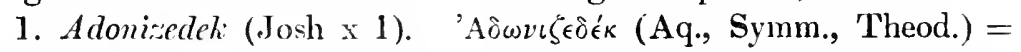

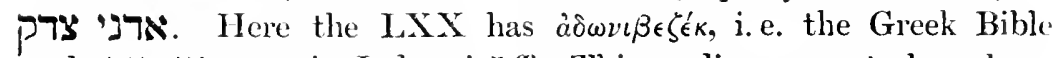
reads ארנדק, as in .Judges i 5 ff. This reading seems to have been corrected to agree with the Hebrew in Origen's Hexapla, with the least possible change of the traditional consonants. Josephus has

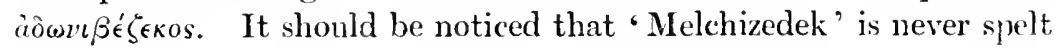
in Greek with $\zeta$ either in the Old or the New 'Testament.

2. Arareth (4 Ezra xiii 45). This is the name of the land where the Ten 'Tribes went, according to the Latin text of 4 Ezra. It appears to denote some region beyond the sonrces of the Euphrates, and against all probability it has been explained as אריץ אחרת, to agree with Deut xxix 28. Not only is the equation of $z$ and $y$ highly contentious: besides that, it is very doubtful whether the word really ended in -areth at all, as the Syriac has mane gir rir.s, i. e. Arsaph, the end of the earth. Certainly this word can do very little to prove that the $\zeta$ in $\mathrm{N} a \zeta a \epsilon^{\prime} \theta$ corresponds to $\boldsymbol{\zeta}$.

3. Bozer (1 Regn xiv 4). The rock Bozez (בוצ') is spelt Bazec in $\mathbf{B}$ and $\beta a \zeta_{\epsilon \theta}$ in 'Lucian'. Presumably the Greek read for בוצי

4. Hezron (Ruth iv 18). The grandson of Judah (דוץר) is spelt 'E $\sigma \rho \omega \mu$ in the NT Genealogies. In the OT we find ' $\mathrm{E} \sigma \rho \dot{\omega} \mu$, 'E $\sigma \rho \omega^{\prime} \mathrm{l}^{\prime}$,

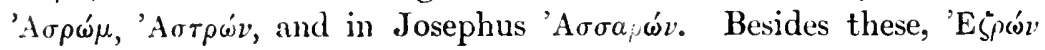
occurs in the Lucianic text of Ruth iv 18, a text which here rests 
upon two minuscules, and 'E $\zeta \rho \omega^{\prime} \mu$ occurs in Lk iii $33 \mathrm{E}$, i.e. in an inferior Uncial of the 8th century. There can be little doubt that these spellings have nothing whatever to do with the writers of the 1.t century A. D.

5. Huz (Gen xxii 21, 1 Chr i 1 $\tilde{\text { ) }}$, the brother of Buz, is spelt in Hebrew $\mathrm{H} M$, the same name as the land of U\%, wherc Job lived. 'The land of $\mathrm{Uz}$ in the Greek Bible is the $\chi \dot{\omega} \rho a$ avं $\tilde{i} \iota s$, while in Genesis we find ${ }^{\prime} \Omega \xi$ and in Chronicles ${ }^{~} \Omega$ s. Josephus has $O \tilde{u} \xi o s$. But the Lucianic text has $\cong \zeta$ for Genesis and Oüs for Chronicles. This again is surely nothing more than a mediaeval rariant in an unfamiliar 'barbarous' word.

6. Duke Mibsar of Edom (Gen xxxri 42, 1 (hr i 53) is spelt Maşáp in the Greek, but Maßráp also occurs. The Hebrew is מבצר.

i. A name casz seems to occur in $1 \mathrm{Chr} x \mathrm{xri} 1+\mathrm{B}$, where the

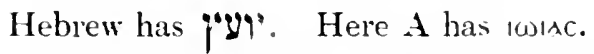

8. Zalmunna, King of Midian (Judges viii $5 \mathrm{ff}$., Psalm lxxxiii 11), appears in the Greek Bible as $\Sigma a \lambda \mu a v$ ' or $\Sigma \in \lambda \mu a r$ 'á. But ' Zeba and

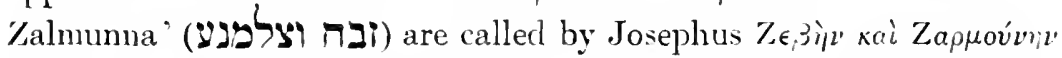
(Antiq. v 228). Is it ton fanciful to suppose that in this instance Josephus modified the name for the sake of alliteration:

9. Zaraces (Ezra A i 38) corresponds to the in' of 2 Chr xxxvi t. It is conceivable that there may have been in the Semitic original

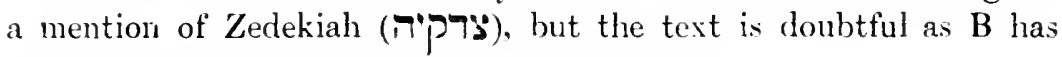
zapion and the Latin Zaracelem and Zachariam.

These nine instances appear to me to be of no importance at all. The case is different with respect to the remaining one :-

10. Zoar, the city near the Dead Sea, where Lot took refuge, in Ilebrew צivis. It is mentioned eleven times in all. In eight of these (Gen xiv 2, 8 ; xix 22, 23, 30 bis; Deut xxxiv 3; Isai xr 5) the Greek Bible has $\Sigma_{\eta}^{\prime} \gamma \omega \rho$, a transliteration which points to a vocalization different from the Massoretic ( use of $y$ for $y$ is characteristic of the earlier Greek transliterations.

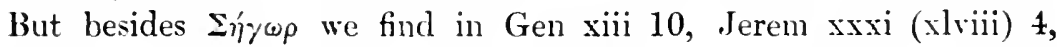
Zóyopa and in Jerem xxxi (xlviii) 34 Zóyop. This is something more than a transcriber's mistake. It is clear that there must have been a definite reason for spelling the name of this town with $Z$.

lo doubt the reason was that 'Zoar' was a known place, spelt Zoápa or Zwápa by Ptolemy (v 16). Eusebius (OS 231) says,

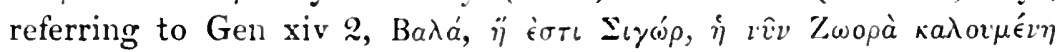

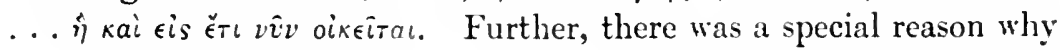
this town should be spelt with $Z$. We know from Gen xix that 
the name was supposed to mean 'Littleham' or 'Littleborough',

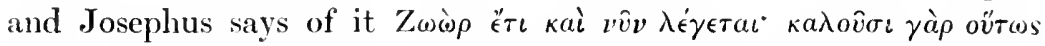

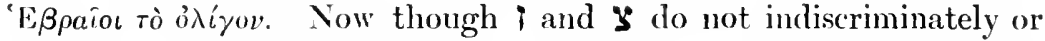
regularly interchange, yet one or two roots containing these letters do interchange, and זעיר is is one of the words for 'little' in Hebrew, while in Jewish Aramaic it is

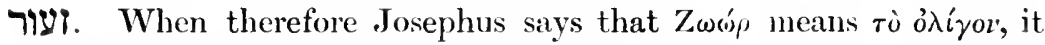
is Aramaic rather than Biblical Ilebrew that he has in mind, and

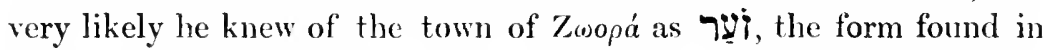
the 'Jerusalem' 'Targum to Gen xiv and xix, and also in the 'Jerusalem' (i. e. Palestinian) 'T'almud.

Somewhat similarly the root tinian Aramaic) instead of צרק so that e.g. the ¿aooovкaio appear regularly in the Syriac versions as איארו But this is an exclusively Syriac form and does not occur even in the Christian Palestinian dialect. 'Thus the names of Zoaran isolated exception to the rule that Greek $Z$ does not correspond to Semitic $\boldsymbol{\xi}$. 'The evidence rather suggests that in historical times this town was known by an Aramaic name (i), rather than by the old Hebraeo-Canaanite one (צער) by which it is called in the Old Testament. It is possible that the more modern Aramaic name harl once a footing in the Old 'Testament itself, and that this stage is reflected by the Greek Bible, in which possibly $\Sigma_{\eta \gamma \omega \rho}$ corresponds

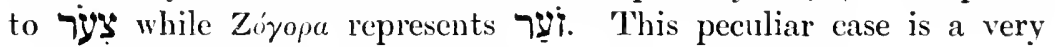
slender foundation for supporting the theory that in Naşasét or Na aa á the second consonant corresponds to a sade and not to a zain. 


\section{INDEX}

Abaddon 7

Abia 8

Abrahain 2

Acre, see Ptolemais

Adonizedek 28

Aenon 13

Agabus 25, 26

Alans, see Elamites

Alphaeus 5, 25, 26

Aunas 6

Arabia 6

Arabs 6

Aretas 8

Arzareth 28

Azotus 8

Barabbas 6

Bar-Jesus, Barshuma 22

Barsabbas 6

Bartholomew 23

Beelzebub 4

Bethabara 4, 9 f., 13, 24

Bethany 4, 13, 14

Bethesda 19f., 24

Bethlehem Serieh $17 \mathrm{n}$.

Bethpluage 6, 13, 24

Bethsaida 6, 9, 17

Bezatha, see Bethesda

Bezeth 20

Boanerges 17

Boaz 8

Bozez 28

Caiaphas 5, 9

Cana $18 \mathrm{f} ., 22$

Canaanite, Cananacan $\delta$

Capernaum 17, 27 f.

Ceplias 5

Chorazin 6, $17 \mathrm{f}$.

Chuza 6
Dalmanutha 15,17

Dule $2 n$.

Flanites 22,23

Gadarenes 1011 .

Gaza 8

Gennesaret 8, 15

Gerar $10 \mathrm{n}$.

Gerasenes 10 и.

Gergesenes, Girgashites $9 \mathrm{t},, 24$

Gethsemane 8

Gusham, Gashmu $23 \mathrm{n}$.

Hagarenes $10 \mathrm{n}$.

Hebrew, Heher $25 \mathrm{f}$.

Iezron 28

Hosanua 5

Huz 29

Isaac 2

'Ii, see Barshuma

Jacob 2

Jairus, Jair 7, 22,24

Jerusalem 4, 12

Jesus, Jesu 6

Jobel, see Obed

Joppa 8

Jordan 13

Joshua 6

Lydda 8

Malchus 23

Mattatha 8

Matthias, see 'Tholomaeus

Melchizedek 28

Mesopotamia 4

Messiah 6

Mibzar 29 


\title{
INDEX
}

Niain 8

Nazara 16

Nazarene, Nazoraean 16, 18

Nazareth 15f, , 21, :4

Nizziriter 16, 18

Oberl \&

Parthians: 22

Peter 5 in.

pharaol :

Pharisees 5

Phylacteries 5, 23

Ptolemais 8, 12, 83

Siadducees $5,: 30$

Salim 13

Sanhedrin 23

\author{
Sapphira 1: \\ Sarepta 28 \\ Saron, Sharon 8 \\ Negor, see Zoar \\ Shinar 10 \\ Sidon :8 \\ Silas 6 \\ Simon, Simeon 0 \\ Sion 4.16 \\ Tabitha .; \\ Talitha :5 \\ Tarsus 8 \\ Thardaeus i; \\ Tholomaens ?:? \\ Zalmunua 29 \\ Zaraces 29? \\ Zoar, Zoara $: 90,30$
}


Date Due 


\section{Oxford}

Printed by Horace Hart, at the University Press 



$$
||||||||||||||||
$$

